\title{
Screening of trace metal supplementation for black water anaerobic digestion
}

\author{
Adriana F. M. Braga, Maria Beatriz O. C. Pereira, Marcelo Zaiat, Gustavo H. R. \\ da Silva \& Fernando G. Fermoso
}

To cite this article: Adriana F. M. Braga, Maria Beatriz O. C. Pereira, Marcelo Zaiat, Gustavo H. R. da Silva \& Fernando G. Fermoso (2018) Screening of trace metal supplementation for black water anaerobic digestion, Environmental Technology, 39:14, 1776-1785, DOI: 10.1080/09593330.2017.1340343

To link to this article: https://doi.org/10.1080/09593330.2017.1340343

Accepted author version posted online: 08 Jun 2017. Published online: 26 Jun 2017.

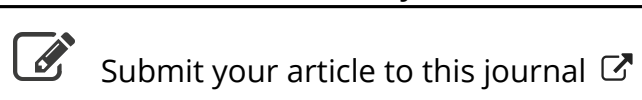

Џ Article views: 128

Q View related articles ¿

View Crossmark data $\asymp$ 


\title{
Screening of trace metal supplementation for black water anaerobic digestion
}

\author{
Adriana F. M. Braga (1) ${ }^{a}$, Maria Beatriz O. C. Pereira ${ }^{b}$, Marcelo Zaiat $\mathbb{1}^{\mathrm{a}}{ }^{\text {, }}$, Gustavo H. R. da Silva ${ }^{\mathrm{b}}$ and \\ Fernando G. Fermoso (i) ${ }^{c}$ \\ ${ }^{a}$ Biological Processes Laboratory, Center for Research, Development and Innovation in Environmental Engineering, São Carlos School of \\ Engineering (EESC), University of São Paulo (USP), São Carlos, Brazil; ${ }^{b}$ Department of Civil and Environmental Engineering, São Paulo State \\ University (UNESP), Bauru, Brazil; 'Instituto de la Grasa (C.S.I.C.), Sevilla, Spain
}

ABSTRACT

Community on-site separation of wastewater is a treatment approach that leads to more efficient processes. Black water has high organic matter content and can be a suitable feedstock for anaerobic treatment systems. Biological methane production (BMP) tests were conducted using Plackett-Burman design to screen the effects of adding $\mathrm{Fe}, \mathrm{Ni}, \mathrm{Cu}, \mathrm{Co}, \mathrm{Mn}, \mathrm{Ba}$ and $\mathrm{Se}$, with simulated black water (SBW) as the substrate. In the inoculum, most metals were found mainly in the organic matter/sulfide and residual fractions except for $\mathrm{Mn}$, which was present at $12.3 \%$ in the bioavailable fractions (exchangeable and carbonates), and $\mathrm{Ba}$, which was evenly distributed among all the fractions. Ba had a significant negative effect on methane production and $\mathrm{Mn}$ addition enhanced the toxic effect. A specific methanogenic activity (SMA) between $18 \%$ and $27 \%$ lower than the control, was predicted at a total Ba concentration of approximately 1000$1200 \mathrm{mg} \mathrm{L}^{-1}$. Similar SMA was predicted at Ba concentration between 400 and $600 \mathrm{mg} \mathrm{L}^{-1}$ when $0.55 \mathrm{mg} \mathrm{L}^{-1}$ of $\mathrm{Mn}$ is added. Se and $\mathrm{Cu}$ additions demonstrate the potential to improve the methane production from SBW. The SMA was predicted to reach $12 \mathrm{mLCH}_{4} \mathrm{gCOD}^{-1} \mathrm{~d}^{-1}$ when $\mathrm{Cu}$ and Se are supplied at total concentrations of $3.0 \mathrm{mg} \mathrm{L}^{-1}$ and $0.98 \mathrm{mg} \mathrm{L}^{-1}$, respectively.
ARTICLE HISTORY Received 11 January 2017 Accepted 6 June 2017

\section{KEYWORDS}

Decentralized sanitation; metal addition; PlackettBurman design; synergic effect of metals; specific methanogenic activity

\section{Introduction}

Many researchers have studied the shift in sanitation systems to improve their overall performance so that wastewater content (water, organic matter and nutrients) can be considered a resource to be recycled rather than a pollutant [1-4].

Community on-site separation of wastewater is attracting considerable interest because it could lead to more efficient wastewater treatment approaches. This separation usually generates two streams: a diluted stream that is commonly named gray water and composed mainly of water from the bath, laundry and kitchen and a concentrated stream that is usually named black water and composed mainly of feces, urine and flush water [2].

The high concentration of organic carbon and relative lower flow of black water compared to gray water make this wastewater a suitable feedstock for on-site anaerobic treatments. Anaerobic digestion (AD) of black water stabilizes the stream and recovers methane, providing the opportunity to further recover nutrients, such as phosphorus and nitrogen [4].
The strategic approach of collecting and treating black water separately represents an effective advance that would facilitate further reduction in the size of wastewater treatment plants [5]. The anaerobic treatment of source-separated domestic wastewater is recognized as the core technology to improve energy recovery from domestic wastewater [4].

On-site black water $A D$ and nitrogen and phosphorus recovery have been demonstrated at the laboratory scale and in some pilot scale experiments in northern European countries [6-9]. Temperature is a key factor in $A D$, and heating of the reactor during cold weather is a major issue. Tropical countries may be able to avoid that problem. Brazil successfully uses anaerobic treatment for sewage, especially because of the high and relatively constant temperature through the year [10]. On-site black water AD might be an attractive option for more efficient sanitation systems in Brazil. The main drawback is the implementation of on-site separation technology in each household, which entails a different tubing configuration, and it would only be feasible during the construction of new buildings. Therefore, to

CONTACT Adriana F. M. Braga adrianabraga@usp.br E Biological Processes Laboratory, Center for Research, Development and Innovation in Environmental Engineering, São Carlos School of Engineering (EESC), University of São Paulo (USP), Engenharia Ambiental - Bloco 4-F, Av. João Dagnone, 1100 - Santa Angelina, 13.563-120, São Carlos, SP, Brazil

๑ 2017 Informa UK Limited, trading as Taylor \& Francis Group 
promote implementation of such technology in future construction, black water treatment should show its advantages and overcome its challenges.

There are several challenges to optimal black water anaerobic treatment, such as mixing, organic loading rate and feeding fluctuation, among others. One factor that is often not considered is whether the feedstock, in this case black water, might be limited by the lack or excess of essential trace metals for anaerobic microbes.

The addition of certain essential trace metals might improve $A D$ because of biological deprivation of these metals. Black water may have high content of certain metals, but their presence does not ensure their bioavailability. Therefore, the addition of some metals might be necessary. Assessments of the appropriate metals, the metal concentration ranges and the possible synergic or antagonistic effects usually result in a complex experimental set-up. Thus, statistically based experimental designs might aid in a first assessment of trace metal limitation or toxicity. Plackett-Burman is a fractional factorial design widely used for screening factors with statistically significant effects on the variable of interest [11].

Among the essential trace metals reported for anaerobic microorganisms, $\mathrm{Fe}, \mathrm{Co}, \mathrm{Ni}$ and Se have been noted for their crucial role in the anaerobic pathway of organic matter digestion. Other trace metals, such as $\mathrm{Cu}, \mathrm{Mn}$ or $\mathrm{Ba}$, have been shown to have an effect on $A D$ processes; however, a clear role in the enzymatic reactions of the anaerobic pathway has not been documented [12]. Metal concentrations or ranges to be added are also critical parameters, as either insufficient addition to overcome limitation or even toxic concentrations may be reached. Different examples can be found in the literature. Evranos and Demirel [13] used $0.5 \mathrm{mg} \mathrm{L}^{-1}, 0.5$ and $0.25 \mathrm{mg} \mathrm{L}^{-1}$ of $\mathrm{Co}$, Ni and Mo, respectively, to enhance methane production from maize silage. Ruel et al. [14] used a Ba concentration of $2 \mathrm{mM}$ (274.654 $\mathrm{mg} \mathrm{L}^{-1}$ ) to inhibit the sulfidogenic activity in an experiment to develop a protocol for biochemical acidogenic potential using municipal sewage as substrate.
Muñoz et al. [15] used a $10 \mathrm{mM}$ Ba solution to enhance enzymatic hydrolysis. Thanh et al. [16] reviewed different trace metal addition cocktails for enhancing methane production in $A D$ systems.

The aim of the present study was to study the distribution of trace metals in an anaerobic inoculum from an upflow anaerobic sludge blanket (UASB) reactor treating sewage, followed by the screening of the effects of addition of different amounts of $\mathrm{Fe}, \mathrm{Ni}, \mathrm{Cu}, \mathrm{Co}, \mathrm{Mn}, \mathrm{Ba}$ and Se on biological methane production (BMP) using the previously studied anaerobic inoculum and a simulated black water (SWB) as feedstock. The addition of different metal ranges was tested by using the statistically based Plackett-Burman experimental design. This design allows studying the individual effect of each metal on the activity of the inoculum fed with the black water under study. The synergic and/or antagonist effects of different groups of metals were studied as well.

\section{Materials and methods}

\section{Inoculum}

The anaerobic inoculum was obtained from a UASB reactor treating domestic sewage from the sewage treatment plant (STP) of São Carlos, São Paulo, Brazil. The sludge was collected from the bottom of the UASB reactor and contained total solids (TS) of $56.96 \pm$ $10.73 \mathrm{gTS} \mathrm{L}^{-1}$ and total volatile solids (TVS) of $36.73 \pm$ $6.50 \mathrm{gVTS} \mathrm{L}^{-1}$. The distribution of metals in the sludge was analyzed according to a modified Tessier method $[17,18]$ (Table 1).

In this modified Tessier method, four fractions are defined. (i) The exchangeable fraction (EXC) accounts for the metals adsorbed to the sludge particles. (ii) The fraction bound to carbonates (CAR) accounts for the metals easily released from the sludge through slight changes in the medium $\mathrm{pH}$. These two fractions are considered easily available for microorganisms and are called bioavailable in the present manuscript. (iii) The

Table 1. Conditions of the sequential extraction method applied to the inoculum following van der Veen et al. [17] with modifications according to Bizzi et al. [18].

\begin{tabular}{|c|c|c|c|c|}
\hline \multirow[b]{2}{*}{ Phase } & \multirow[b]{2}{*}{ Fraction } & \multirow[b]{2}{*}{ Extracting agent } & \multicolumn{2}{|c|}{ Extraction conditions } \\
\hline & & & Shaking time (min) & Temperature $\left({ }^{\circ} \mathrm{C}\right.$ \\
\hline 1 & Exchangeable (EXC) & $\begin{array}{c}10 \mathrm{~mL} \mathrm{NH}_{4} \mathrm{CH}_{3} \mathrm{COO} \\
(1 \mathrm{M}, \mathrm{pH} \mathrm{7})\end{array}$ & 60 & $20-25$ \\
\hline 2 & Carbonates (CAR) & $\begin{array}{c}10 \mathrm{~mL} \mathrm{CH} \mathrm{CHOH}_{3} \mathrm{COOH} \\
(1 \mathrm{M}, \mathrm{pH} 5.5)\end{array}$ & 60 & $20-25$ \\
\hline 3 & Organic matter + sulfides $(\mathrm{OM}+\mathrm{S})$ & $\begin{array}{c}5 \mathrm{~mL} \mathrm{H}_{2} \mathrm{O}_{2} \\
(30 \% \mathrm{pH} 2)\end{array}$ & 240 & 30 \\
\hline 4 & Residual (RES) & $\begin{array}{c}5 \mathrm{~mL} \mathrm{HNO}_{3}(3 \mathrm{M})+2 \mathrm{~mL} \\
\mathrm{H}_{2} \mathrm{O}_{2}(30 \%)^{\mathrm{a}}\end{array}$ & - & - \\
\hline
\end{tabular}

\footnotetext{
${ }^{\mathrm{a}}$ Condition defined by Bizzi et al. [18].
} 
fraction bound to organic matter plus sulfides $(\mathrm{OM}+\mathrm{S})$ accounts for metals already incorporated by the microorganism in the sludge, bound to humic acids and/or precipitated with sulfide. (iv) The residual fraction (RES) accounts for metals attached to inert particles. The sum of the EXC and CAR fractions has been considered the bioavailable fraction of the inoculum because the metals are weakly attached to the sludge. The total metal concentration in the sludge was obtained by summing the four fractions (Table 2), which were analyzed in duplicate.

To initiate the sequential extraction protocol, the sludge volume required to obtain approximately $1 \mathrm{~g}$ of TS was centrifuged (6000 rpm for $10 \mathrm{~min}$ ). After the supernatant was discharged, the sequential extraction scheme (Table 1) was applied to the solid fraction. A glovebox workstation (UNIlab Plus, MBRAUN, Germany) was used to avoid oxidation of metals in the extraction of phases 1 (EXC) and 2 (CAR). Centrifugation (4000 rpm for $10 \mathrm{~min}$ ) was applied to separate the extracted liquid phase between the extractions. A microwave (Four Speed, Berghof $\mathrm{GmbH}$, Germany) was used to digest the residual fraction (RES). After the samples were digested, they were filtered (Whatman ${ }^{\circ}$ 589/1, SigmaAldrich, MO, USA) and diluted to $100 \mathrm{~mL}$ in volumetric flasks.

The metal concentrations of each extracted fraction were determined by inductively coupled plasma optical emission spectrometry (ICP-OES) (Optima 8000, Perkin Elmer, USA). The parameters applied to the ICP-OES spectrometer were radio frequency (RF) power: $1300 \mathrm{~W}$, argon plasma flow rate: $8 \mathrm{~L} \mathrm{~min}^{-1}$, auxiliary argon flow rate: $0.3 \mathrm{~L} \mathrm{~min}^{-1}$, nebulizer argon flow rate: $0.80 \mathrm{~L} \mathrm{~min}^{-1}$ and sample flow: $1.0 \mathrm{~L} \mathrm{~min}^{-1}$. An internal standard (yttrium at $1 \mathrm{mg} \mathrm{L}^{-1}$ ) was added as an internal standard. Each standard calibration curve was prepared with the respective matrix used in the extraction procedure.

Table 2. Total metal content in the inoculum from sludge from a UASB reactor treating domestic sewage.

\begin{tabular}{lc}
\hline Metal & Metal concentration $\left(\mathrm{mg} \mathrm{gTS}^{-1}\right)$ \\
\hline $\mathrm{Al}$ & $30.44 \pm 0.36$ \\
$\mathrm{As}$ & $0.02 \pm 0.00$ \\
$\mathrm{Ba}$ & $0.05 \pm 0.00$ \\
$\mathrm{Cd}$ & $0.00 \pm 0.00$ \\
$\mathrm{Co}$ & $0.01 \pm 0.00$ \\
$\mathrm{Cr}$ & $0.36 \pm 0.01$ \\
$\mathrm{Cu}$ & $0.45 \pm 0.01$ \\
$\mathrm{Fe}$ & $4.31 \pm 0.01$ \\
$\mathrm{~K}$ & $2.79 \pm 0.29$ \\
$\mathrm{Mg}$ & $2.74 \pm 0.02$ \\
$\mathrm{Mn}$ & $0.15 \pm 0.00$ \\
$\mathrm{Ni}$ & $0.20 \pm 0.00$ \\
$\mathrm{~Pb}$ & $0.02 \pm 0.00$ \\
$\mathrm{~S}$ & $29.12 \pm 0.74$ \\
$\mathrm{Se}$ & $0.01 \pm 0.00$ \\
$\mathrm{Zn}$ & $1.47 \pm 0.01$ \\
\hline
\end{tabular}

Table 3. Characteristics of the SBW compared with values listed in the literature.

\begin{tabular}{lccccc}
\hline Parameter & $\begin{array}{c}\text { SBW (this } \\
\text { work) }\end{array}$ & $\begin{array}{c}\text { SBW } \\
{[19]}\end{array}$ & $\begin{array}{c}\text { Black Water } \\
{[20]}\end{array}$ & $\begin{array}{c}\text { Black water } \\
{[21]}\end{array}$ & $\begin{array}{c}\text { Black water } \\
{[22]}\end{array}$ \\
\hline COD $\left(\mathrm{g} \mathrm{L}^{-1}\right)$ & 7.60 & 2.28 & 9.80 & $0.9-1.50$ & 9.67 \\
TKN & 203 & $809^{\mathrm{a}}$ & 1900 & $100-300$ & 1030 \\
$\quad\left(\mathrm{mgN} \mathrm{L}^{-1}\right)$ & & & & & \\
$\begin{array}{c}\text { P-total } \\
\left(\mathrm{mgP} \mathrm{L}^{-1}\right)\end{array}$ & 45 & 16 & 220 & $40-90$ & 91 \\
\hline
\end{tabular}

${ }^{\mathrm{a}}$ Total nitrogen $\left(\mathrm{mgN} \mathrm{L}^{-1}\right)$.

\section{Simulated black water}

The SBW was prepared using swine slaughterhouse wastewater and domestic sewage at a 3:1 ratio, resulting in chemical oxygen demand (COD) of $7.60 \mathrm{~g} \mathrm{~L}^{-1}$, to achieve characteristics similar to other reported black waters (Table 3).

The domestic sewage was collected at the STP of São Carlos, São Paulo, Brazil after a primary pretreatment for removal of coarse materials, sand and grit followed by a Parshall flume with a $\mathrm{pH}$ controller, which maintained the inlet $\mathrm{pH}$ value at approximately 7.0 by adding $\mathrm{NaHCO}_{3}$. The swine slaughterhouse wastewater was obtained at the swine slaughterhouse Big Board in São Carlos, Brazil. The swine slaughterhouse wastewater was collected at the entrance of an anaerobic lagoon at $10 \mathrm{~cm}$ below the surface. The metal concentration in the SBW was determined after microwave digestion following the same procedure as for the previously described RES fraction. The metal concentrations in the SBW were analyzed in duplicate, and the averages and standard deviations are presented at Table 4.

\section{BMP tests}

The BMP test is a powerful tool to study trace metal effects. However, the possible effect of metal on an anaerobic process is mostly reflected by the methane

Table 4. Concentration of metals in the SBW.

\begin{tabular}{lc}
\hline Elements & Concentration $\left(\mathrm{mg} \mathrm{L}^{-1}\right)$ \\
\hline $\mathrm{Al}$ & $6.68 \pm 0.13$ \\
$\mathrm{As}$ & $\mathrm{n} / \mathrm{d}$ \\
$\mathrm{Ba}$ & $0.01 \pm 0.01$ \\
$\mathrm{Cd}$ & $\mathrm{n} / \mathrm{d}$ \\
$\mathrm{Co}$ & $0.01 \pm 0.00$ \\
$\mathrm{Cr}$ & $\mathrm{n} / \mathrm{d}$ \\
$\mathrm{Cu}$ & $1.24 \pm 0.02$ \\
$\mathrm{Fe}$ & $4.05 \pm 0.21$ \\
$\mathrm{~K}$ & $177.20 \pm 0.71$ \\
$\mathrm{Mg}$ & $35.30 \pm 0.25$ \\
$\mathrm{Mn}$ & $1.01 \pm 0.00$ \\
$\mathrm{Ni}$ & $0.08 \pm 0.01$ \\
$\mathrm{~Pb}$ & $0.07 \pm 0.04$ \\
$\mathrm{~S}$ & $171.05 \pm 30.90$ \\
$\mathrm{Se}$ & $0.82 \pm 0.23$ \\
$\mathrm{Zn}$ & $2.86 \pm 0.06$ \\
\hline
\end{tabular}


production rate not the final methane yield. The methane production rate is highly dependent on the inoculum quality and the BMP set-up. Currently, the BMP test for kinetic studies of a certain substrate or condition should only be used if the inoculum and the BMP set-up are similar in all the planned experiments.

BMP tests were performed in glass bottles with $250 \mathrm{~mL}$ of working volume and $350 \mathrm{~mL}$ of headspace. The amount of inoculum biomass added to the bottles was $2.94 \pm 0.52 \mathrm{gTVS} \mathrm{L}^{-1}$, resulting in $4.56 \pm$ $0.86 \mathrm{gTS} \mathrm{L}^{-1}$. A volume of $50 \mathrm{~mL}$ of SBW was added to all bottles, resulting in a COD of $1415.23 \pm$ $149.19 \mathrm{mg} \mathrm{L}^{-1}$. The resulting metal contributions of the inoculum biomass and SBW in each BMP test are presented in Table 5.

Different volumes of the studied trace metals were also added. The complementary volume to achieve the working volume was filled with ultrapure water (Milli-Q, Millipore, USA). To ensure anaerobic conditions, the headspace in the bottles was purged with a $\mathrm{N}_{2} / \mathrm{CO}_{2}$ (70:30) gas mixture for $3 \mathrm{~min}$. All BMP tests were performed in duplicate in a chamber at a controlled temperature $\left(32.1 \pm 0.6^{\circ} \mathrm{C}\right)$, and agitation was applied before measuring the pressure inside the bottles. The biogas production was monitored using a TPR-18 pressure transducer coupled to a BS 2200 interface (Desin Instruments, Barcelona, ESP). To follow the composition of the biogas, headspace samples were analyzed once a week using a gas chromatography (GC) (GC 2010, Shimadzu, Kyoto, Japan). The GC 2010 contained a thermal conductivity detector, a Carboxen 1010 capillary column ( $L \times I . D$. $30 \mathrm{~m} \times 0.53 \mathrm{~mm}$, average thickness $30 \mu \mathrm{m}$ ) and argon as

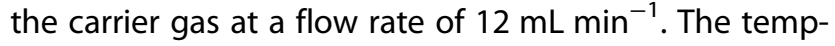
eratures of the injector, column and detector were $200^{\circ} \mathrm{C}, 130^{\circ} \mathrm{C}$ and $230^{\circ} \mathrm{C}$, respectively.

Table 5. Concentration of metals in the BMP tests related to the addition of inoculum and SBW.

\begin{tabular}{lcc}
\hline & \multicolumn{2}{c}{ Concentration in the BMP test $\left(\mathrm{mg} \mathrm{L}^{-1}\right)$} \\
\cline { 2 - 3 } Metals & From inoculum & From SBW \\
\hline $\mathrm{Al}$ & $138.72 \pm 1.63$ & $1.34 \pm 0.03$ \\
$\mathrm{As}$ & $0.07 \pm 0.00$ & $\mathrm{n} / \mathrm{a}$ \\
$\mathrm{Ba}$ & $0.23 \pm 0.00$ & $0.00 \pm 0.00$ \\
$\mathrm{Cd}$ & $0.01 \pm 0.00$ & $0.00 \pm 0.00$ \\
$\mathrm{Co}$ & $0.03 \pm 0.00$ & $0.00 \pm 0.00$ \\
$\mathrm{Cr}$ & $1.64 \pm 0.05$ & $0.00 \pm 0.00$ \\
$\mathrm{Cu}$ & $2.03 \pm 0.05$ & $0.25 \pm 0.00$ \\
$\mathrm{Fe}$ & $19.61 \pm 0.05$ & $0.81 \pm 0.04$ \\
$\mathrm{~K}$ & $12.72 \pm 1.30$ & $35.44 \pm 0.14$ \\
$\mathrm{Mg}$ & $12.50 \pm 0.09$ & $7.06 \pm 0.05$ \\
$\mathrm{Mn}$ & $0.69 \pm 0.0$ & $0.20 \pm 0.00$ \\
$\mathrm{Ni}$ & $0.90 \pm 0.01$ & $0.02 \pm 0.00$ \\
$\mathrm{~Pb}$ & $0.08 \pm 0.01$ & $0.01 \pm 0.01$ \\
$\mathrm{~S}$ & $132.71 \pm 3.34$ & $34.21 \pm 6.18$ \\
$\mathrm{Se}$ & $0.03 \pm 0.01$ & $0.16 \pm 0.05$ \\
$\mathrm{Zn}$ & $6.68 \pm 0.05$ & $0.57 \pm 0.01$ \\
\hline
\end{tabular}

Using Origin 8.0 software (OriginLab' ${ }^{\circ}$, Northampton, MA, USA), the Boltzmann equation was adjusted to the raw data of the percentage of $\mathrm{CH}_{4}$ to estimate the biogas composition when only pressure data were available. The Boltzmann equation was applied again to adjust for the production of $\mathrm{CH}_{4}$ against time, and then the derivative of this curve was taken to obtain the methane production rate or, as defined in the present manuscript, specific methanogenic activity (SMA) expressed as $\mathrm{mL}$ of produced methane per gram of added COD per day.

\section{Plackett-Burman design}

The metal addition screening experiment was planned by the statistically based Plackett-Burman experimental design [23]. The screening experiment was performed to determine which metal among the seven tested ( $\mathrm{Fe}$, $\mathrm{Ni}, \mathrm{Cu}, \mathrm{Co}, \mathrm{Mn}, \mathrm{Ba}$ and $\mathrm{Se}$ ) had a significant effect on the AD of the SBW. This design of the experiment generated a matrix formed by the high level and low level of the factors and a center point, which was set to the difference between the high and low level divided by 2. The matrix of trace metal concentrations was constructed using Statistica 64 software (Dell Inc., Tulsa, OK, USA) (Table 6).

In the low level, the metals were only provided by the SBW and the inoculum, with no external addition. Considering that the SBW was a composite of complex organic matter, requiring all steps of $A D$, the center point was set to 10 fold the trace metal media used by Worm et al. [24] to evaluate the SMA using only propionate, formate, acetate and $\mathrm{H}_{2} / \mathrm{CO}_{2}$ as substrates. Evranos and Demirel [13] used similar concentrations of Co and $\mathrm{Ni}$ as the ones adopted in this study to enhance methane production from maize silage. Ruel et al. [14] used $2 \mathrm{mM}$ Ba concentration (274.654 $\mathrm{mg} \mathrm{L}^{-1}$ ) to inhibit the sulfidogenic activity in an experiment to propose a protocol for biochemical acidogenic potential. Muñoz et al. [15] used a $10 \mathrm{mM}$ Ba solution to enhance

Table 6. Matrix of added metals concentrations in the PlackettBurman design.

\begin{tabular}{llllllcl}
\hline & \multicolumn{7}{c}{ Concentration added to the bottles $\left(\mathrm{mg} \mathrm{L}^{-1}\right)$} \\
\cline { 2 - 8 } Run & $\mathrm{Fe}$ & $\mathrm{Ni}$ & $\mathrm{Co}$ & $\mathrm{Se}$ & $\mathrm{Cu}$ & $\mathrm{Ba}$ & $\mathrm{Mn}$ \\
\hline 1 & 0 & 0 & 0 & 0.79 & 0.64 & 1373.3 & 0 \\
2 & 0 & 0 & 0.59 & 0.79 & 0 & 0 & 0.55 \\
3 & 0 & 0.59 & 0 & 0 & 0.64 & 0 & 0.55 \\
4 & 0 & 0.59 & 0.59 & 0 & 0 & 1373.3 & 0 \\
$5^{\mathrm{a}}$ & 2.79 & 0.29 & 0.29 & 0.39 & 0.32 & 686.64 & 0.27 \\
6 & 5.58 & 0 & 0 & 0 & 0 & 1373.3 & 0.55 \\
7 & 5.58 & 0 & 0.59 & 0 & 0.64 & 0 & 0 \\
8 & 5.58 & 0.59 & 0 & 0.79 & 0 & 0 & 0 \\
9 & 5.58 & 0.59 & 0.59 & 0.79 & 0.64 & 1373.3 & 0.55 \\
\hline a Center point. & & \multicolumn{7}{c}{} & &
\end{tabular}


enzymatic hydrolysis, the same concentration as used in the present study. Trace metals in the same order of magnitude as Table 6 were used in other studies reviewed by Thanh et al. [16]. A control bottle, without metal addiction, was also added to the assay to compare to the model prediction.

Based on the Plackett-Burman matrix results, a firstorder polynomial model was fit, and the effect of the metals on this model was evaluated by the ANOVA test, using Statistica 64 software (Dell Inc., Tulsa, OK, USA). Surface plots were built based on the model fitted to assess the synergic/antagonistic interaction among metal and predict the SMA resulted from the different supplementation combination.

\section{General analysis}

The COD, total Kjeldahl nitrogen (TKN), total phosphorus (TP), TS and TVS were measured according to APHA et al. [25]. The dissolved metal concentrations were determined by ICP-OES (Optima 8000, Perkin Elmer, USA). The parameters applied to the ICP-OES spectrometer were RF power: $1300 \mathrm{~W}$, argon plasma flow rate: $8 \mathrm{~L} \mathrm{~min}^{-1}$, auxiliary argon flow rate: $0.3 \mathrm{~L} \mathrm{~min}^{-1}$, nebulizer argon flow rate: $0.80 \mathrm{~L} \mathrm{~min}^{-1}$ and sample flow: $1.0 \mathrm{~L} \mathrm{~min}^{-1}$. The internal standard yttrium at was added $1 \mathrm{mg} \mathrm{L}^{-1}$ to the samples.

\section{Results and discussion}

\section{Fractionation of trace metals in the inoculum}

Sequential metal extraction was applied to the anaerobic inoculum obtained from a UASB reactor treating domestic sewage. The fractionation of the seven metals of interest $(\mathrm{Ba}, \mathrm{Co}, \mathrm{Cu}, \mathrm{Fe}, \mathrm{Mn}, \mathrm{Ni}$ and $\mathrm{Se}$ ) is presented in Figure 1.

$\mathrm{Ni}$ and Se were present at concentrations of 0.198 and $0.005 \mathrm{mg} \mathrm{gTS}^{-1}$, respectively. Despite the concentrations being at different orders of magnitude in the inoculum, $\mathrm{Ni}$ and $\mathrm{Se}$ showed similar fractionation. Approximately $78 \%$ of each was bound to the $\mathrm{OM}+\mathrm{S}$ fraction, and approximately $22 \%$ was found in the RES fraction. The strong retention of these two metals in the inoculum indicates that $\mathrm{Ni}$ and $\mathrm{Se}$ are difficult to be up taken by microorganisms. For $\mathrm{Co}, 72.7 \%$ of the total content in the sludge $\left(5.84 \mathrm{\mu g} \mathrm{gTS}^{-1}\right)$ was found in the $\mathrm{OM}+\mathrm{S}$ fraction, $26.7 \%$ was found in the RES fraction and only $0.5 \%$ was bound in the more bioavailable fractions (the sum of EXC and CAR fractions), resulting in $0.031 \mathrm{\mu g} \mathrm{gTS}^{-1}$. From the total concentration of $\mathrm{Cu}$ in the sludge, $0.446 \mathrm{mg} \mathrm{gTS}^{-1}$ or $68.6 \%$ was bound in the $\mathrm{OM}+\mathrm{S}$ fraction and $31.3 \%$ was found in the RES

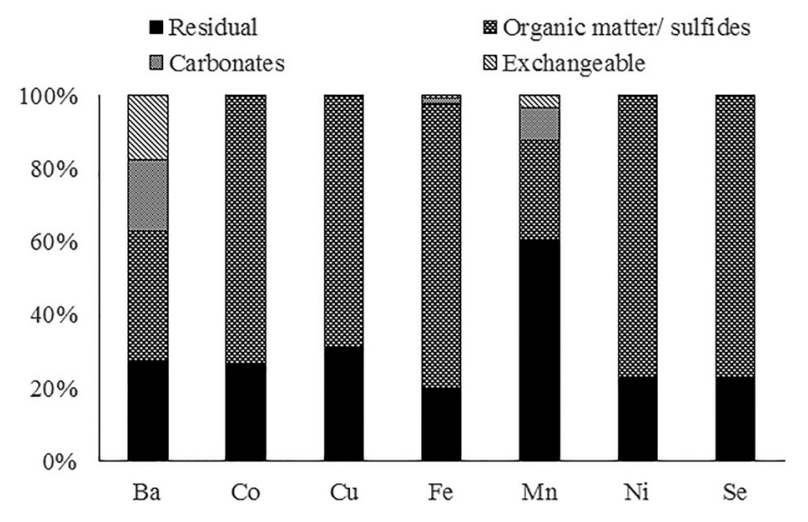

Figure 1. Proportions of $\mathrm{Ba}, \mathrm{Co}, \mathrm{Cu}, \mathrm{Fe}, \mathrm{Mn}, \mathrm{Ni}$ and Se from the inoculum in the four fractions of the used modified Tessier sequential extraction.

fraction. Only $0.1 \%$ of the $\mathrm{Cu}$ was present in the CAR fraction, representing $0.48 \mu \mathrm{g} \mathrm{TS}^{-1}$. Mn had the highest percentage in RES fraction, $60.7 \%$ of the total $\mathrm{Mn}$ concentration. However, $\mathrm{Mn}$ was found at significant percentages in the more bioavailable fractions, with $3.3 \%$ and $9.0 \%$ present in the EXC and CAR fractions, respectively, representing a bioavailable concentration of $\mathrm{Mn}$ equal to $0.019 \mathrm{mg} \mathrm{gTS}^{-1}$. Ba was the most equally distributed metal among the fractions, considering its total concentration in the sludge, with $17.7 \%$ and $19.6 \%$ measured in the most bioavailable fractions EXC and CAR, respectively, resulting in a concentration of $0.019 \mathrm{mg} \mathrm{gTS}^{-1}$, while $27.4 \%$ and $35.2 \%$ were present in the less bioavailable RES and $\mathrm{MO}+\mathrm{S}$ fractions, respectively. Fe had $78 \%$ of its total content bound to the $\mathrm{OM}+\mathrm{S}$ fraction, $20 \%$ bound in the RES fraction and $0.7 \%$ and $1.5 \%$ bound in the more bioavailable fractions EXC and CAR, respectively. The total Fe concentration was the highest concentration among the metals analyzed, $4.305 \mathrm{mg} \mathrm{gTS}^{-1}$, and the concentration readily available for the microorganisms (the sum of EXC and (AR) was also the highest, $0.091 \mathrm{mg} \mathrm{gTS}^{-1}$. Because it appears at a higher order of magnitude of concentration than the other metals, Fe is usually considered a macronutrient.

Osuna et al. [26] performed sequential extractions of the $\mathrm{Co}, \mathrm{Ni}, \mathrm{Se}, \mathrm{Mo}, \mathrm{Mn}, \mathrm{Cu}, \mathrm{Zn}, \mathrm{Ca}, \mathrm{Fe}$ and $\mathrm{Mg}$ in the sludges from alcohol distillery and paper mill wastewater $A D$ treatments. The authors found that these metals were mostly in the $\mathrm{OM}+\mathrm{S}$ and RES fraction except for $\mathrm{Ca}$, which was in the more bioavailable fractions due the carbonate and adsorption in the sludge, and Mn, which was more equally distributed among the fractions. The fractionation by sequential extraction was also performed by Zandvoort et al. [27] for $\mathrm{Co}, \mathrm{Ni}, \mathrm{Fe}, \mathrm{Mn}$, Se, Mo, $\mathrm{Zn}$ and $\mathrm{Cu}$. These authors analyzed four sludges 
from anaerobic digesters treating alcohol distillery wastewater, paper mill wastewater, groundwater contaminated with perchloroethene and brewery wastewater. Despite the diverse sources of sludge, most of the metals analyzed were found in the $\mathrm{OM}+\mathrm{S}$ and RES fractions, although $\mathrm{Mn}$ was found at a higher percentage in the CAR fraction and showed a similarity with the inoculum of BMP tests used in this study. Se was barely detectable in the sludges in both studies, corroborating the results obtained in this work.

Considering the concentrations from the fractionation data and making the assumption that the EXC and CAR concentrations have the most bioavailable concentration of the studied metals, the metal bioavailability in the inoculum follows the sequence $\mathrm{Fe}>\mathrm{Ba}=$ $\mathrm{Mn}>>\mathrm{Ni}>\mathrm{Cu}>>\mathrm{Co}>\mathrm{Se}$. It may be assumed that the metal content in the SBW will be as bioavailable as these two fractions. The bioavailability sequence resulting from the sum of metals from the SBW and the EXC and CAR fractions of the sludge would be $\mathrm{Fe}>>\mathrm{Mn}>$ $\mathrm{Cu}>\mathrm{Se}>\mathrm{Ba}>\mathrm{Ni}>>\mathrm{Co}$. This assumption should be further studied because the SBW has a high TS content, which could indicate higher RES and $\mathrm{OM}+\mathrm{S}$ fractions than expected.

\section{Metal effect on black water AD}

The specific methanogenic activities of the PlackettBurman experimental design are shown in Table 7. From these data, a first-order polynomial model was fitted $\left(R^{2}=0.82\right.$ and $\left.R_{\mathrm{adj}}=0.70\right)$ and the coefficients estimated.

ANOVA was applied to analyze the statistical significance of the single effect of each metal on the variable response, SMA. The standardized magnitude of the effects, the magnitude divided by their respective standard errors, and their probability is shown in Figure 2. $\mathrm{Se}$ and $\mathrm{Cu}$ had a positive effect under the studied range, although it was weakly significant. No enzyme participating in methanogenesis is known to be Cu dependent [12]. Nevertheless, Oleszkiewicz and Sharma [28] stated that $\mathrm{Cu}$ is related to the hydrogenases of facultative anaerobes and Clostridia, which is crucial to the acidogenesis step of AD. Se has been shown to play a crucial role in methanogenesis (Banks et al. [29]); therefore, a positive effect was expected.

Ba addition in the studied range negatively affected the methanogenic activity of the inoculum. The concentration range used was clearly above the toxic range. Muñoz et al. [15] used this same concentration, which clearly improved the hydrolytic enzymatic activity in their experiments. Although $\mathrm{Ba}$ has not been shown to occur in any enzyme of the $A D$ pathway, it has been reported to reduce the competition of sulfidogenic microorganisms for the methanogenic substrate by precipitating $\mathrm{SO}_{4}^{-2}[14]$ and enhance enzymatic hydrolysis [15]. In the present study, we can hypothesize that this Ba concentration is likely toxic for other pathways such as acetogenesis or methanogenesis. However, no studies on Ba toxicity in these anaerobic pathways have been reported so far.

$\mathrm{Mn}$ affected methanogenesis negatively as well but not as strongly as $B a$. The function of $M n$ in $A D$ has been described in the literature as a stabilizer for methyltransferase of methanogens [28] and as an electron donor for methane formation from $\mathrm{CO}_{2}$ [30]. Wu et al. [31] reported that the addition of $\mathrm{Mn}$ improved the methanogenic production rate in de-oiled grease trap waste digestion. In the present study, $\mathrm{Mn}$ influenced the inoculum negatively, which is inconsistent with the results of a previous study with much higher metal addition ranges.

Co is a component of enzymes involved in the three methanogenic pathways: hydrogenotrophic in the carbon monoxide dehydrogenase/acetyl-CoA and acetoclastic and methylotrophic in methyltransferases [12]. Several studies have reported limitations because of a lack of Co $[29,32,33]$, and others indicated inhibition because of excess addition [34]. In the present study, Co had a negative effect on the SMA in the studied range, indicating that the Co addition had reached the inhibition level.

Table 7. SMA results of the Plackett-Burman assay.

\begin{tabular}{|c|c|c|c|c|c|c|c|c|}
\hline \multirow[b]{2}{*}{ Run } & \multicolumn{7}{|c|}{ Total concentration in the bottles $\left(\mathrm{mg} \mathrm{L}^{-1}\right)$} & \multirow{2}{*}{$\begin{array}{c}\text { SMA } \\
\left(\mathrm{mLCH}_{4} \mathrm{gCOD}^{-1} \mathrm{~d}^{-1}\right)\end{array}$} \\
\hline & $\mathrm{Fe}$ & $\mathrm{Ni}$ & Co & Se & $\mathrm{Cu}$ & $\mathrm{Ba}$ & $\mathrm{Mn}$ & \\
\hline 1 & 20.43 & 0.92 & 0.03 & 0.98 & 2.92 & 1373.50 & 0.89 & $9.37 \pm 1.20$ \\
\hline 2 & 20.43 & 0.92 & 0.62 & 0.98 & 2.28 & 0.23 & 1.44 & $10.41 \pm 0.17$ \\
\hline 3 & 20.43 & 1.51 & 0.03 & 0.19 & 2.92 & 0.23 & 1.44 & $10.42 \pm 0.87$ \\
\hline 4 & 20.43 & 1.51 & 0.62 & 0.19 & 2.28 & 1373.50 & 0.89 & $7.61 \pm 0.35$ \\
\hline 5 & 23.22 & 1.21 & 0.32 & 0.58 & 2.60 & 686.87 & 1.16 & $8.09 \pm 0.06$ \\
\hline 6 & 26.01 & 0.92 & 0.03 & 0.19 & 2.28 & 1373.50 & 1.44 & $7.75 \pm 0.48$ \\
\hline 7 & 26.01 & 0.92 & 0.62 & 0.19 & 2.92 & 0.23 & 0.89 & $11.04 \pm 0.75$ \\
\hline 8 & 26.01 & 1.51 & 0.03 & 0.98 & 2.28 & 0.23 & 0.89 & $11.24 \pm 1.12$ \\
\hline 9 & 26.01 & 1.51 & 0.62 & 0.98 & 2.92 & 1373.50 & 1.44 & $7.52 \pm 0.37$ \\
\hline
\end{tabular}




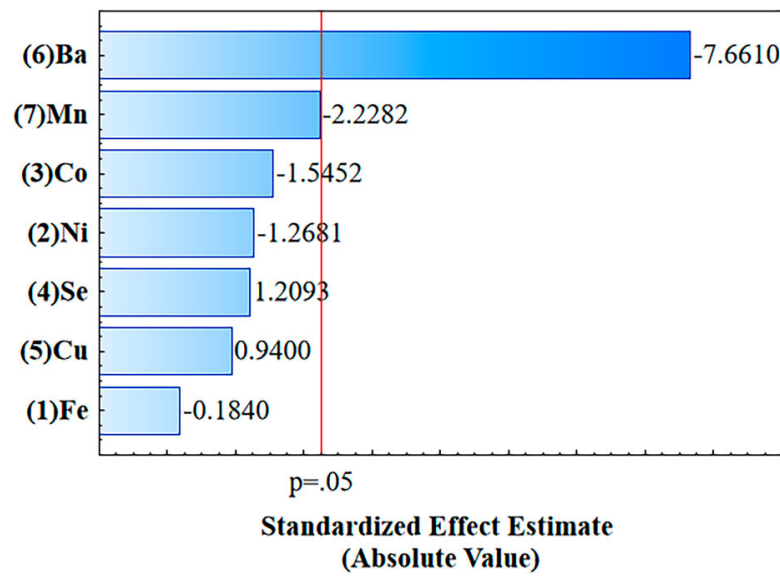

Figure 2. Pareto's chart of standardized effects estimated.

$\mathrm{Ni}$ is important for methanogenesis because it is the core of the coenzyme F430, which is exclusive to methanogenic archaea and contained in the methyl coenzyme $M$ reductase [35]. As shown by Fermoso et al. [36] and Pobeheim et al. [37], low availability of $\mathrm{Ni}$ may limit anaerobic systems. Nonetheless, $\mathrm{Ni}$ addition did not produce a significant effect in the studied range.

Fe plays an important role in AD pathways and forms Fe-S clusters involved in electron transport and catalysis [12]. Fe-Fe hydrogenase, which is related to acidogenesis, and methane monooxygenase, which participates in the methane production [38,39]. Nevertheless, as with $\mathrm{Co}$ and $\mathrm{Ni}$, Fe did not show a significant effect on the AD of the SWB in the studied range.

\section{Synergic and/or antagonist effect of the two negative factors ( $\mathrm{Ba}$ and $\mathrm{Mn}$ ) and the two positive factors (Se and $\mathrm{Cu}$ ) on the AD of black water}

The fitted first-order polynomial model was used to estimate the SMA under different concentrations of $\mathrm{Ba}$ and $\mathrm{Mn}$ and assess their synergic and/or antagonist effects and surface plots (Figure 3) were built to visualize the effect of the interaction. Although Se and Cu were only weakly significant ( $p$-values of .26 and .37 , respectively), their synergic and/or antagonist effect on SMA were also evaluated using the surface plots because these two metals presented a positive effect in the studied range. For building the surfaces, $\mathrm{Fe}, \mathrm{Ni}$ and $\mathrm{Co}$ were set to their concentration values without addition.

The negative effect of $\mathrm{Ba}$ on SMA was enhanced by the presence of $\mathrm{Mn}$ (Figure 3(A)). A SMA value between 9.25 and $8.25 \mathrm{mLCH}_{4} \mathrm{gCOD}^{-1} \mathrm{~d}^{-1}$ was estimated to occur at a total $\mathrm{Ba}$ concentration of approximately 1000-1200 mg. $\mathrm{L}^{-1}$ and a minimum Mn concentration. However similar SMA values, between 9.25 and $8.25 \mathrm{mLCH}_{4} \mathrm{gCOD}^{-1} \mathrm{~d}^{-1}$, for much lower Ba concentrations between 400 and $600 \mathrm{mg} \mathrm{L}^{-1}$ was found by adding $0.55 \mathrm{mg} \mathrm{L}^{-1}$ of $\mathrm{Mn}$. Because the SBW contained a concentration of sulfur equal to $34.21 \mathrm{mg} \mathrm{L}^{-1}, \mathrm{Ba}$ could have precipitated with $\mathrm{SO}_{4}^{-2}$ [14], thereby minimizing the sulfide formation that would lead to precipitation of other metals, such as $\mathrm{Mn}$, and making these metals more available in case of further supplementation. According to Qiao et al. [30], Mn can enhance the methanogenic hydrogenotrophic pathway by acting as an electron donor via the addition of $2 \mathrm{~g} \mathrm{~L}^{-1}$ of elemental Mn or directly through the transfer of electrons via Mn oxidation (likely by Firmicutes) via the addition of or $8 \mathrm{~g} \mathrm{~L}^{-1}$ of elemental Mn. However, $\mathrm{MnCl}_{2}$ was added in this study, and further oxidation from $\mathrm{Mn}$ (II) to $\mathrm{Mn}$ (IV) for donating electrons and producing $\mathrm{CH}_{4}$ is highly unlikely. Indeed, because $\mathrm{Mn}$ was already in the more available fractions of the sludge, the possible increment in bioavailable $\mathrm{Mn}$ because of favorable Ba precipitation with carbonate [40] might have led to concentrations of bioavailable $\mathrm{Mn}$ closer to the inhibitory range.

As indicated by the fractionation of the metals (Figure 1), $\mathrm{Cu}$ and Se were the least available metals, which support the evidence that the supplementation of these metals might be necessary for enhancing the methane production from SBW. Figure 3(B) shows that concentrations of $\mathrm{Cu}$ and Se higher than 0.88 and $0.19 \mathrm{mg} \mathrm{L}^{-1}$, respectively, might be necessary to supply the needs for Se and $\mathrm{Cu}$ in a sewage microbial system. The prediction for SMA without any metal addition is $11.17 \mathrm{mLCH}_{4} \mathrm{gCOD}^{-1} \mathrm{~d}^{-1}$, which is close to the value of SMA obtained for the control bottle, $11.25 \mathrm{mLCH}_{4} \mathrm{gCOD}^{-1} \mathrm{~d}^{-1}$. The model estimates that by supplementing the media with these metals, the SMA can be improved to values over $12 \mathrm{mLCH}_{4} \mathrm{gCOD}^{-1} \mathrm{~d}^{-1}$ (Figure 3(B)). Ariunbaatar et al. [41] verified an increase of $30-35 \%$ in $\mathrm{CH}_{4}$ formation by adding $25-50 \mu \mathrm{g} \mathrm{L}^{-1}$ of Se. These authors reported that supplementation of Se resulted in a decrease of acetic and propionic acids in the batch assays. Because $\mathrm{Cu}$ is linked to an improvement of hydrogenase activity [28], its synergism with Se is expected.

Ba has a strong effect on SMA even when metals with positive effects are added. The surface plot showed an SMA gradient almost parallel to the axis of concentration of $\mathrm{Cu}$ and $\mathrm{Se}$, which resulted in a strictly negative correlation of SMA with the Ba concentration and a minimal increase in the response by the addition of $\mathrm{Cu}$ or $\mathrm{Se}$ (Figure 3(C,D)).

The negative effect of Mn on SMA can be minimized by the presence of either Se or $\mathrm{Cu}$ (Figure 3(E,F)). The SMA value of $11 \mathrm{mLCH}_{4} \mathrm{gCOD}^{-1} \mathrm{~d}^{-1}$ resulting from a total $\mathrm{Mn}$ concentration of $1.0 \mathrm{mg} \mathrm{L}^{-1}$ could be increased up to $11.4 \mathrm{mLCH}_{4} \mathrm{gCOD}^{-1} \mathrm{~d}^{-1}$ by having a total Cu concentration of $3.0 \mathrm{mg} \mathrm{L}^{-1}$ or a total Se concentration of 

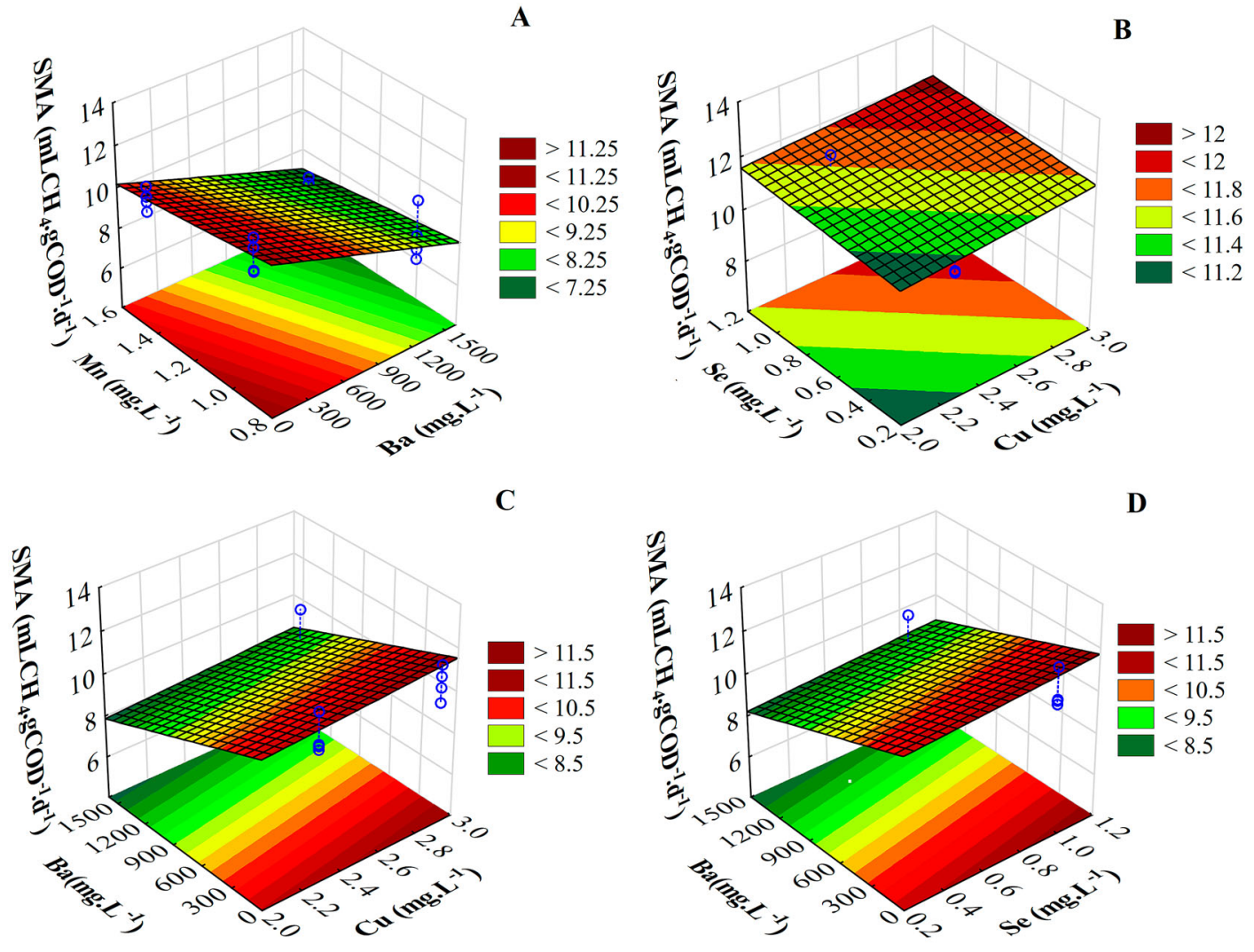

$\mathbf{E}$
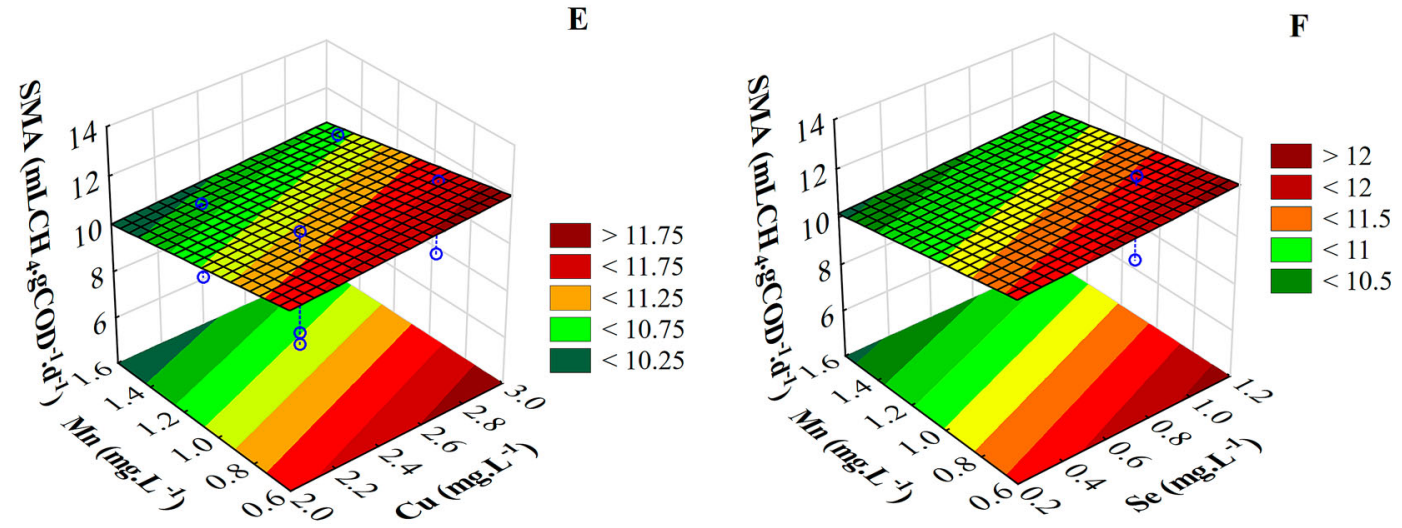

Figure 3. Synergic and/or antagonist effect of $\mathrm{Ba}, \mathrm{Mn}$, Se and $\mathrm{Cu}$ on the SMA of the simulated $\mathrm{AD}$ of black water. (A) $\mathrm{Mn}$ and $\mathrm{Ba}$, (B) $\mathrm{Cu}$ and $\mathrm{Se},(\mathrm{C}) \mathrm{Ba}$ and $\mathrm{Cu},(\mathrm{D}) \mathrm{Ba}$ and $\mathrm{Se},(\mathrm{E}) \mathrm{Mn}$ and $\mathrm{Cu}$ and $(\mathrm{F}) \mathrm{Mn}$ and Se.

$1.0 \mathrm{mg} \mathrm{L}^{-1}$. When both $\mathrm{Cu}$ and Se are added in the above-mentioned concentrations along with $1.0 \mathrm{mg} \mathrm{L}^{-1}$ $\mathrm{Mn}$, the model estimates an improvement in SMA to $11.8 \mathrm{mLCH}_{4} \mathrm{gCOD}^{-1} \mathrm{~d}^{-1}$.

\section{Conclusion}

- Most of the metals analyzed were found mainly in the $\mathrm{OM}+\mathrm{S}$ and residual fractions, except for $\mathrm{Mn}$, which was present at $12.3 \%$ in the bioavailable fractions (EXC and CAR), and Ba, which was evenly distributed in the various fractions.
- Under the studied ranges of metal addition, $\mathrm{Fe}, \mathrm{Ni}$ and Co did not show a clear effect on the AD of black water.

- Ba negatively affected the methanogenic activity of the inoculum in the studied range. A SMA between $18 \%$ and $27 \%$ lower than the control, $11.17 \mathrm{mLCH}_{4} \mathrm{gCOD}^{-1} \mathrm{~d}^{-1}$, was predicted at a total $\mathrm{Ba}$ concentration of approximately 1000$1200 \mathrm{mg} \mathrm{L}^{-1}$.

- The negative effect of Ba on SMA was enhanced by the presence of Mn. Similar SMA was predicted at Ba concentration between 400 and $600 \mathrm{mg} \mathrm{L}^{-1}$ when $0.55 \mathrm{mg} \mathrm{L}^{-1}$ of $\mathrm{Mn}$ is added. 
- The negative effect of Mn on SMA was minimized by the presence of either Se and/or Cu. The SMA value of $11 \mathrm{mLCH}_{4} \mathrm{gCOD}^{-1} \mathrm{~d}^{-1}$ resulting from a total $\mathrm{Mn}$ concentration of $1.0 \mathrm{mg} \mathrm{L}^{-1}$ could be increased up to $11.4 \mathrm{mLCH}_{4} \mathrm{gCOD}^{-1} \mathrm{~d}^{-1}$ by having a total Cu concentration of $3.0 \mathrm{mg} \mathrm{L}^{-1}$ or a total Se concentration of $1.0 \mathrm{mg} \mathrm{L}^{-1}$.

- Se and $\mathrm{Cu}$ additions demonstrate the potential to improve the methane production from SBW. The SMA was predicted to reach $12 \mathrm{mLCH}_{4} \mathrm{gCOD}^{-1} \mathrm{~d}^{-1}$ when $\mathrm{Cu}$ and Se are supplied at total concentrations of $3.0 \mathrm{mg} \mathrm{L}^{-1}$ and $0.98 \mathrm{mg} \mathrm{L}^{-1}$, respectively.

\section{Disclosure statement}

No potential conflict of interest was reported by the authors.

\section{Funding}

This research was supported by the Conselho Nacional de Desenvolvimento Científico e Tecnológico under the grants 406751/2013-7, 150521/2014-6, 150641/2015-0 and 150475/ 2016-0; the Coordenação de Aperfeiçoamento de Pessoal de Nível Superior (CAPES) and Fundação de Amparo à Pesquisa do Estado de São Paulo under the Grant FAPESP - Process 2013/50351-4.

\section{ORCID}

Adriana F. M. Braga (D) http://orcid.org/0000-0003-3464-2469 Marcelo Zaiat (D) http://orcid.org/0000-0001-7336-9093

Fernando G. Fermoso (D) http://orcid.org/0000-0002-2586-007X

\section{References}

[1] Larsen TA. Redesigning wastewater infrastructure to improve resource efficiency. Water Sci Technol. 2011;63:2535-2541.

[2] Otterpohl R. Options for alternative types of sewerage and treatment systems directed to improvement of the overall performance. Water Sci Technol. 2002;45:149-158.

[3] Thibodeau C, Monette F, Glaus M. Comparison of development scenarios of a black water source-separation sanitation system using life cycle assessment and environmental life cycle costing. Resour Conserv Recycl. [Internet]. 2014;92:38-54. doi:10.1016/j.resconrec.2014. 08.004

[4] Zeeman G, Kujawa K, de Mes T, et al. Anaerobic treatment as a core technology for energy, nutrients and water recovery from source-separated domestic waste(water). Water Sci Technol. [Internet]. 2008;57:1207-1212. http:// www.ncbi.nlm.nih.gov/pubmed/18469391

[5] Sharma MK, Kazmi AA. Anaerobic onsite treatment of black water using filter-based packaged system as an alternative of conventional septic tank. Ecol Eng.
[Internet]. 2015;75:457-461. doi:10.1016/j.ecoleng.2014. 12.014

[6] de Wilt A, Butkovskyi A, Tuantet K, et al. Micropollutant removal in an algal treatment system fed with source separated wastewater streams. J Hazard Mater. 2016;304:84-92.

[7] Kujawa K. Anaerobic treatment of concentrated wastewater in desar concepts. Utrecht: STOWA; 2005.

[8] Fernandes TV, Shrestha R, Sui Y, et al. Closing domestic nutrient cycles using microalgae. Environ Sci Technol. 2015;49:12450-12456.

[9] Tervahauta $T$, van der Weijden RD, Flemming RL, et al. Calcium phosphate granulation in anaerobic treatment of black water: a new approach to phosphorus recovery. Water Res. 2014;48:632-642.

[10] Chernicharo CAL. Anaerobic reactors: biological wastewater treatment series (volume 4). 1st ed. London: IWA Publishing; 2007.

[11] Wang J, Wan W. Experimental design methods for fermentative hydrogen production: a review. Int J Hydrog Energ. [Internet]. 2009;34:235-244. Available from: http:// linkinghub.elsevier.com/retrieve/pii/S0360319908013608

[12] Glass JB, Orphan VJ. Trace metal requirements for microbial enzymes involved in the production and consumption of methane and nitrous oxide. Front Microbiol. [Internet]. 2012 [cited 2014 May 1];3:61. Available from: http://www.pubmedcentral.nih.gov/ articlerender.fcgi?artid=3282944\&tool=pmcentrez\&rende rtype $=$ abstract

[13] Evranos B, Demirel B. The impact of Ni, Co and Mo supplementation on methane yield from anaerobic monodigestion of maize silage. Environ Technol. [Internet]. 2015;36:1556-1562. Available from: http://www. tandfonline.com/doi/abs/10.1080/09593330.2014.997297

[14] Ruel SM, Comeau Y, Héduit A, et al. Operating conditions for the determination of the biochemical acidogenic potential of wastewater. Water Res. 2002;36:2337-2341.

[15] Muñoz C, Fermoso FG, Rivas M, et al. Hydrolytic enzyme activity enhanced by barium supplementation. AIMS Microbiol. [Internet]. 2016;2:402-411. Available from: http://www.aimspress.com/article/10.3934/microbiol. 2016.4.402

[16] Thanh PM, Ketheesan B, Yan Z, et al. Trace metal speciation and bioavailability in anaerobic digestion: a review. Biotechnol Adv. [Internet]. 2016;34:122-136. doi:10.1016/ j.biotechadv.2015.12.006

[17] van der Veen a., Fermoso FG, Lens PNL. Bonding form analysis of metals and sulfur fractionation in methanolgrown anaerobic granular sludge. Eng. Life Sci. [Internet]. 2007 [cited 2014 May 6];7:480-489. doi:10. 1002/elsc.200720208

[18] Bizzi C, Flores ELM, Nóbrega J, et al. Evaluation of a digestion procedure based on the use of diluted nitric acid solutions and $\mathrm{H}_{2} \mathrm{O}_{2}$ for the multielement determination of whole milk powder and bovine liver by ICP-based techniques. J Anal Atom Spectrom. [Internet]. 2014;29:332, Available from: http://xlink.rsc.org/? doi:10.1039/c3ja50330e

[19] Vogl A, Bischof F, Wichern M. Single chamber microbial fuel cells for high strength wastewater and blackwater treatment - a comparison of idealized wastewater, synthetic human blackwater, and diluted pig manure. 
Biochem Eng J. [Internet]. 2016;115:64-71. doi:10.1016/j. bej.2016.08.007

[20] de Graaff MS, Temmink H, Zeeman G, et al. Anaerobic treatment of concentrated black water in a UASB reactor at a short HRT. Water. 2010;2:101-119.

[21] Henze M, Ledin A. Types, characteristics and quantities of classic, combined wastewaters. In: Lens P, Zeeman G, Lettinga $G$, editors. Decentralised sanitation and reuse: concepts, systems and implementation. London: IWA Publishing; 2001. p. 57-72.

[22] Elmitwalli TA, Van Leeuwen M, Kujawa-Roeleveld K, et al. Anaerobic biodegradability and digestion in accumulation systems for concentrated black water and kitchen organic-wastes. Water Sci Technol. 2006;53:167-175.

[23] Plackett RL, Burman JP. The design of optimum multifactorial experiments. Biometrika. 1946;33:305-325.

[24] Worm P, Fermoso FG, Lens PNL, et al. Decreased activity of a propionate degrading community in a UASB reactor fed with synthetic medium without molybdenum, tungsten and selenium. Enzyme Microb. Technol. 2009;45:139-145.

[25] APHA, AWWA, WEF. Standard methods for the examination of water and wastewater. 21st ed. Washington, DC: American Public Health Association; 2005.

[26] Osuna MB, van Hullebusch ED, Zandvoort MH, et al. Effect of cobalt sorption on metal fractionation in anaerobic granular sludge. J Environ Qual. [Internet]. 2004;33:1256-1270. http://www.ncbi.nlm.nih.gov/pubmed/15254107

[27] Zandvoort MH, van Hullebusch ED, Gieteling J, et al. Granular sludge in full-scale anaerobic bioreactors: trace element content and deficiencies. Enzyme Microb Technol. [Internet]. 2006 [cited 2014 May 14];39:337346. Available from: http://linkinghub.elsevier.com/ retrieve/pii/S0141022906001712

[28] Oleszkiewicz J, Sharma VK. Stimulation and inhibition of anaerobic processes by heavy metals: a review. Biol Wastes. 1990;31:45-67.

[29] Banks CJ, Zhang Y, Jiang Y, et al. Trace element requirements for stable food waste digestion at elevated ammonia concentrations. Bioresour Technol. [Internet]. 2012;104:127-135. doi:10.1016/j.biortech.2011.10.068

[30] Qiao S, Tian T, Qi B, et al. Methanogenesis from wastewater stimulated by addition of elemental manganese. Sci Rep. [Internet]. 2015;5:1200. Available from: http:// www.nature.com/srep/2015/150805/srep12732/full/ srep12732.html
[31] Wu L-J, Kobayashi T, Kuramochi H, et al. Effects of potassium, magnesium, zinc, and manganese addition on the anaerobic digestion of de-oiled grease trap waste. Arab J Sci Eng. [Internet]. 2016;41:2417. doi:10.1007/s13369015-1879-3

[32] Fermoso FG, Collins G, Bartacek J, et al. Acidification of methanol-fed anaerobic granular sludge bioreactors by cobald deprivation: induction and microbial community dynamics. Biotechnol Bioeng. 2008;99:49-58.

[33] Gustavsson J, Shakeri Yekta S, Sundberg C, et al. Bioavailability of cobalt and nickel during anaerobic digestion of sulfur-rich stillage for biogas formation. Appl Energ. [Internet]. 2013;112:473-477. doi:10.1016/j. apenergy.2013.02.009

[34] Pinto-lbieta F, Serrano A, Jeison D, et al. Effect of cobalt supplementation and fractionation on the biological response in the biomethanization of Olive Mill Solid Waste. Bioresour Technol. 2016;211:58-64.

[35] Mulrooney SB, Hausinger RP. Nickel uptake and utilization by microorganisms. FEMS Microbiol Rev. 2003;27:239261.

[36] Fermoso FG, Collins G, Bartacek J, et al. Role of nickel in high rate methanol degradation in anaerobic granular sludge bioreactors. Biodegradation. 2008;19:725-737.

[37] Pobeheim $H$, Munk $B$, Lindorfer $H$, et al. Impact of nickel and cobalt on biogas production and process stability during semi-continuous anaerobic fermentation of a model substrate for maize silage. Water Res. [Internet]. 2011;45:781-787. doi:10.1016/j.watres.2010.09. 001

[38] Vignais PM, Colbeau A. Molecular biology of microbial hydrogenases. Curr Issues Mol Biol. 2004;6:159-188.

[39] Fermoso FG, Bartacek J, Jansen S, et al. Metal supplementation to UASB bioreactors: from cell-metal interactions to full-scale application. Sci Total Environ. [Internet]. 2009;407:3652-3667. doi:10.1016/j.scitotenv.2008.10.043

[40] Park S, Bang JH, Song K, et al. Barium carbonate precipitation as a method to fix and utilize carbon dioxide. Chem Eng J. 2016;284:1251-1258.

[41] Ariunbaatar J, Esposito G, Yeh DH, et al. Enhanced anaerobic digestion of food waste by supplementing trace elements: role of selenium (VI) and iron (II). Front Environ Sci. [Internet]. 2016;4:1-11. Available from: http://journal.frontiersin.org/Article/10.3389/fenvs.2016. 00008/abstract 